\title{
Is the Decision to Apply LEISA Related to Decision Making Stage?
}

\author{
Siti Wahana*, Mutia Intan Savitri Herista \\ Department of Agribusiness \\ Swadaya Gunung Jati University \\ Cirebon, Indonesia \\ *sitiwa6@gmail.com
}

\author{
Ismail Saleh \\ Department of Agrotechnology, Agriculture \\ Swadaya Gunung Jati University \\ Cirebon, Indonesia
}

\author{
Ray March Syahadat \\ Department of Landscape Architecture \\ National Institute of Science and Technology \\ Jakarta, Indonesia \\ raymarch.syahadat@gmail.com
}

\begin{abstract}
Indonesia government establish program organic agriculture called Go Organic 2010. This program appear because government aware of the danger posed by the use of synthetic chemical in agriculture. Implication of this program are counselling and training about organic agriculture held almost all over Indonesian farmers applied LEISA. They applied compost fertilizer and organic pesticides thus decrease synthetic chemical in agriculture. This research aim to characterize the farmers in Jatianom Village, Cirebon Regency and relationship between stages of decision making as well as to apply the LEISA. This research used 47 farmers as samples. The relationship between stage of decision making and decision making to application LEISA were analysed by using chi-square goodnes of fit. The results showed that most farmers age are 45-54 years (41\%), most farmers education background was elementary school $(51,1 \%)$, lowland farmers in general are narrow, ie 0,51-1 ha $(38,3 \%)$. Farmer's income in general less than 20 million/growth session $(42,6 \%)$. Based on the results of chisquare analysis with $\alpha=95 \%$ was found that stage of decision making has relationship with decision making farmer to application LEISA like recognition, persuasive, application and confirmation stage.
\end{abstract}

Keywords: decision making, stage of decision making, LEISA

\section{INTRODUCTION}

Entering 21st century, the world community realize about the danger pose by the use synthetic chemicals in agriculture. Agriculture system with high input energy can reduce soil fertility and damage environment. This awareness makes the world community switch to use sustainable agriculture include in Indonesia. Indonesia government establishes organic agriculture in 2010, as a sustainable agriculture program called Go Organic 2010. Implication of this program are counselling and training about organic agriculture held almost all over Indonesia include in Jatianom Village Susukan Cirebon. It is difficult to change their habit which is maybe almost applied in whole life of farmer. One of the alternative solution about this is using low external input of sustainable agriculture or usually known as LEISA.

LEISA is one way to reach organic farming. Cultivation with LEISA, farmer still using chemical fertilizer and chemical pesticides but limited. The principle of this cultivation is tried to be in harmony with nature and use much organic ingredients to avoid negative effect of synthetic chemical in agriculture.

There are five stages of decision making. There are recognition, persuasive, decision, application and confirmation. Recognition stage is the stage that farmers begin to recognize about healthy farming. Observed from the stages in agricultural cultivation. The persuasive stage, the stage where the respondent is willing or unwilling towards healthy farming. The decision making stage for implementing or not implementing healthy agriculture. Confirmation, the stage when respondents begin to seek reinforcement in healthy farming decisions. Sub district Jatianom has the biggest lowland in District Susukan Region Cirebon. District Susukan is one of the producer of Beras in Cirebon. Almost 70 percent people in Jatianom Village is farmer. The area of agricultural land in Jatianom Village, Susukan Sub-District spreads evenly without hills. The majority of the occupations of residents in Jatianom Village are rice farmers. Jatianom village has 4 hamlets. Each hamlet is led by the hamlet head. Farmers in Jatianom Village like farmers in Indonesia generally use conventional farming methods. This cultivation method has been used for decades. This causes a decrease in land quality. The decrease in land quality causes the need for inorganic fertilizers to increase to produce the same amount of production. Nevertheless, farmers again use conventional farming methods. The purpose of this research was to study the characteristics of farmer in Jatianom and the relationship between stage of decision making and decision making to application LEISA agriculture. 


\section{METHODS}

The research was conducted on November to December 2018 at Jatianaom Village, Susukan District, Cirebon Regency, Indonesia. The method that used was descriptive research. The information was collected from direct observation, interview with farmers and survey to 47 farmers as samples. Relationship between stage of decision making and decision making to application LEISA was analysed with Chi-Square Goodness of Fit [1].

\section{RESULTS AND DISCUSSION}

\section{A. Characteristic of Farmer}

1) Age of farmer: Age of farmers is an important factor in the success of farming. Age is directly related to work productivity [2]. Based on the results of research on the age of farmers in the village of Jatianom, the age classification can be seen at Table 1 .

TABLE I. AGE OF FARMER

\begin{tabular}{|l|l|l|l|}
\hline No. & Age ( Years Old ) & Amount (Person) & Percentage (\%) \\
\hline 1 & $>65$ & 6 & 12.8 \\
\hline 2 & $55-64$ & 10 & 21.3 \\
\hline 3 & $45-54$ & 19 & 40.4 \\
\hline 4 & $35-44$ & 10 & 21.3 \\
\hline 5 & $22-34$ & 2 & 4.3 \\
\hline \multicolumn{2}{|l|}{ Total } & 47 & 100 \\
\hline
\end{tabular}

Based on the table above the farmers in Jatianom Village, Susukan District, Cirebon Regency are mostly in the age range of 45-54 years which is equal to $40.4 \%$. The age range is at the productive age. Productive age is the age where the population is active in working and producing goods and services [3]. But there are also farmers who are already outside the productive age (over 65 years) of $12.8 \%$. Farmers who are outside the productive age and still manage rice fields are usually because they are used to working so that if the farmers do not work they will lose their daily habits.

2) Level of education: The level of education will affect the way of life and one's ability to absorb a new technology or innovation. The ability to absorb a new technology or innovation is expected to increase farmers' productivity. The education level of farmers has a positive and significant effect on the productivity of coffee plants [4]. The results of research on the level of education of farmers can be seen in table 2 .

TABLE II. LEVEL OF EDUCATION

\begin{tabular}{|l|l|l|l|}
\hline No. & \multicolumn{1}{|c|}{ Level of education } & $\begin{array}{c}\text { Number of } \\
\text { (people) }\end{array}$ & $\begin{array}{c}\text { Percentage } \\
(\mathbf{\%})\end{array}$ \\
\hline 1 & $\begin{array}{l}\text { Did not complete elementary } \\
\text { school / no school }\end{array}$ & 12 & 25.5 \\
\hline 2 & SD (Elementary school) & 24 & 51.1 \\
\hline 3 & SMP (junior high school) & 4 & 8.5 \\
\hline 4 & SMA (Senior high school) & 6 & 12.8 \\
\hline 5 & S1/S2/S3 (Bachelor) & 1 & 2.1 \\
\hline Total & 39 & 100 \\
\hline
\end{tabular}

Based on table 2 it is known that the majority of farmers in Jatianom village have low education, because more than $50 \%$ just graduate from elementary school. This low level of education will affect the way of thinking and the ability of farmers to absorb new information and technology. Farmers who are in this low level of education almost occur in every region in Indonesia. The link between the level of education and the application of organic agriculture needs to be explored further if the government wants the Go Organic 2010 program going well and successfully.

3) Land area: Land is one of the factors of production that supports farming. The more land area to cultivate is expected to produce more results by farmers. The land area of respondent farmers in Jatianom Village can be seen in table 3.

TABLE III. LAND AREA

\begin{tabular}{|l|l|l|l|}
\hline No. & \multicolumn{1}{|c|}{ Land Area } & Number of people & Percentage (\%) \\
\hline 1 & $0.05-0.5$ & 11 & 23.4 \\
\hline 2 & $0.51-1.00$ & 18 & 38.3 \\
\hline 3 & $1.01-1.50$ & 4 & 8.5 \\
\hline 4 & $1.51-2.00$ & 4 & 8.5 \\
\hline 5 & $>2.00$ & 10 & 21.3 \\
\hline \multicolumn{2}{|l|}{ Total } & 47 & 100 \\
\hline
\end{tabular}

Table 3 shows that the majority of farmers in Jatianom village have a land area of $0.51-1$ hectare $(38.3 \%)$. This means that farmers in Jatianom Village are included in small farmers. The narrow land area, of course, farmers' income will also be small. The influence between the small income and the application of organic farming will be further analysed. According to the $2013 \mathrm{Bps}$ data, the area of land controlled per Agriculture Business Household by West Java in 2013 was $2,372.85 \mathrm{~m} 2$ on the type of agricultural land (rice fields). This means that the majority of respondent farmers in Jatianom village have a land area above the area of farm households in West Java [5].

4) Income level: The majority of farmers' income levels in Jatianom Village are fewer than 40 million rupiah. This is related with the area of land owned by farmers in Jatianom Village, which is mostly in the range of $0.05-1$ ha. Land area will certainly be directly proportional to the income owned by farmers. But there are also farmers who have income above 100 million rupiah per season. These farmers are usually farmers who have their own land and even rent their land to other farmers. The income owned by farmers will certainly affect the standard of living of these farmers. The greater the income received, the higher the standard of living of farmers.

TABLE IV. INCOME LEVELS

\begin{tabular}{|l|l|l|l|}
\hline No. & Revenue (RpM / Season) & $\begin{array}{c}\text { Number of } \\
\text { people }\end{array}$ & $\begin{array}{c}\text { Percentage } \\
(\%)\end{array}$ \\
\hline 1 & $<20$ & 20 & 42.6 \\
\hline 2 & $20.1-40$ & 15 & 31.9 \\
\hline 3 & $40.1-60$ & 3 & 6.4 \\
\hline 4 & $60.1-80$ & 3 & 6.4 \\
\hline 5 & $80.1-100$ & 4 & 8.5 \\
\hline 6 & $>100$ & 2 & 4.3 \\
\hline \multicolumn{2}{|l|}{ Total } & 47 & 100 \\
\hline
\end{tabular}




\section{B. Relationship between Stages of Decision Making with Decision Making to Application LEISA Agriculture}

1) Recognition stage: The introduction phase is the first stage in the decision-making process of farmers applying or not applying organic farming. This introduction phase can be seen from the introduction of farmers to organic farming cultivation techniques which include seeds used in organic farming, land preparation processes, planting processes, maintenance / fertilization processes and differences in cultivation between organic and non-organic rice cultivation. The results of the study of the introduction stage are described in table 5.

Based on the chi square data introduction stage in the application of organic agriculture in Jatianom Village has asymp value. sig is below $<0.05$. This means that the introduction stage is significantly related to the decision making of respondent farmers in Jatianom Village. The detailed explanation of this introduction stage will be explained in Table 5 .

TABLE V. RECOGNITION STAGE

\begin{tabular}{|l|l|l|l|}
\hline \multicolumn{1}{|c|}{ Variable } & \multicolumn{1}{c|}{$\begin{array}{c}\text { Observed } \\
\text { N }\end{array}$} & $\begin{array}{c}\text { Expected } \\
\text { N }\end{array}$ & Residual \\
\hline $\begin{array}{l}\text { Very low: farmers do not } \\
\text { know / know 1 stage }\end{array}$ & 4 & 9,4 & $-5,4$ \\
\hline Low: farmers know 2 stages & 1 & 9,4 & $-8,4$ \\
\hline Being: farmers know 3 stages & 1 & 9,4 & $-8,4$ \\
\hline $\begin{array}{l}\text { Height: the farmer knows 4 } \\
\text { stages }\end{array}$ & 4 & 9,4 & $-5,4$ \\
\hline $\begin{array}{l}\text { Very high: the farmer knows } \\
\text { 5 stages }\end{array}$ & 37 & 9,4 & 27,6 \\
\hline
\end{tabular}

The majority of respondent farmers in Jatianom Village know about organic farming cultivation techniques as many as 37 people because they know the 5 stages in organic farming cultivation. As many as 4 people know 4 stages. 1 person who knows 3 and 2 stages of organic farming cultivation and 4 people who know 1 stage in organic farming cultivation. In 2010 the government launched the Go Organic Indonesia 2010 program. In order to succeed the program, the government vigorously echoed the importance of organic agriculture. One impact is that the government gives a lot counselling and training on organic farming. Jatianom village is one of the villages that received the program. Jatianom Village is one of the centres of rice-producing villages in Susukan District, Cirebon Regency. This phenomenon is in accordance with the fact because majority of farmers in Jatianom Village are familiar with the stages in organic farming cultivation so long.

2) Persuasive stage: The persuasion stage is the second stage in farmers' decision making in implementing organic farming. The persuasion stage is the stage where farmers begin to decide whether they are willing or not pleased in making decisions on the application of organic farming. The stage of favoring or not pleasing in this study was illustrated by farmers 'interest in organic farming and farmers' efforts in finding information about organic farming.

Based on the data of the chi-square stage the persuasion is significantly related to the decision making of the respondent farmers in Jatianom Village. This is indicated by the asymp value. sig is 0.004 which means it is below $<0.05$. The details of the description of respondents in the persuasive stage can be seen in Table 6

TABLE VI. PERSUASIVE Stage

\begin{tabular}{|l|l|l|l|}
\hline \multicolumn{1}{|c|}{ Variable } & \multicolumn{1}{|c|}{$\begin{array}{c}\text { Observed } \\
\text { N }\end{array}$} & $\begin{array}{c}\text { Expected } \\
\text { N }\end{array}$ & Residual \\
\hline Very low: not interested & 18 & 9,4 & 8,6 \\
\hline $\begin{array}{l}\text { Low: not interested but } \\
\text { looking for information }\end{array}$ & 2 & 9,4 & $-7,4$ \\
\hline Is: interested & 9 & 9,4 &,- 4 \\
\hline $\begin{array}{l}\text { High: interested \& } \\
\text { looking for information }\end{array}$ & 6 & 9,4 & $-3,4$ \\
\hline $\begin{array}{l}\text { Interested, looking for } \\
\text { information and } \\
\text { immediately try }\end{array}$ & 12 & 9,4 & 2,6 \\
\hline
\end{tabular}

In the persuasion stage, respondent farmers in Jatianom Village were not interested in organic farming as many as 18 people. The farmers who were interested and immediately tried were 12 people. The respondents who are interested but are still looking for information, are interested and interested and are looking for information for 17 people. This shows that the respondents are actually still there are curious indications but have not dared to try in the cultivation of organic agriculture.

Respondent farmers in Jatianom Village have known about organic farming. Because of this they can see the advantages and advantages of organic and non-organic farming. Based on the strengths and weaknesses of the farmers there are indications of being interested and pleased with organic farming cultivation.

3) Decision stage: The decision making stage for implementing or not implementing healthy agriculture. The result show that decision stage is not significantly related to the decision making of respondent farmers in Jatianom Village.

\section{TABLE VII. DECISION STAGE}

\begin{tabular}{|l|l|l|l|}
\hline \multicolumn{1}{|c|}{ Variable } & $\begin{array}{c}\text { Observed } \\
\text { N }\end{array}$ & $\begin{array}{c}\text { Expected } \\
\mathbf{N}\end{array}$ & Residual \\
\hline Very low: farmers refuse & 9 & 11,8 & $-2,8$ \\
\hline $\begin{array}{l}\text { Medium: farmers apply } \\
\text { because } \\
\text { implementation of renewal } \\
\text { agents }\end{array}$ & 10 & 11,8 & $-1,8$ \\
\hline $\begin{array}{l}\text { High: farmers are attracted } \\
\text { because of other people's } \\
\text { success / the influence of } \\
\text { others }\end{array}$ & 18 & 11,8 & 6,3 \\
\hline $\begin{array}{l}\text { Very high: farmers apply } \\
\text { because of their full } \\
\text { awareness of themselves }\end{array}$ & 10 & 11,8 & $-1,8$ \\
\hline
\end{tabular}

A total of 18 respondent farmers in Jatianom village or most of them applied organic farming because they saw other farmers succeed and then affected. After the farmer knows and determines deign or not deign, farmers determine the attitude of applying or not applying organic farming. Jatianom Village 
farmers form a less pleasing attitude but feel interested in implementing organic farming. Farmers still open in the case of implementing organic farming and they will more interested for implemented it if they see other farmer success or get influenced by other.

4) Implementation stage: The implementation phase of the respondent farmer in the decision to apply organic farming can be seen in table 8 . The Implementation stage is significantly related to the decision making of the respondent farmer in Jatianom Village. The majority of respondent farmers have implemented sustainable agriculture but stopped as many as 28 people. As many as 11 respondent farmers continued to apply organic farming with a fixed planting area and only one respondent farmer who implemented an increase in planting area. This is when related to the decision of the respondent farmers who mostly refused because the respondent farmers applied organic farming due to coercion from other parties. These other parties are reform agents such as extension agents or village officials. Farmer respondents also have a tendency to apply organic farming because of the success of others and the influence of others.

TABLE VIII. IMPLEMENTATION STAGE

\begin{tabular}{|l|l|l|l|}
\hline \multicolumn{1}{|c|}{ Variable } & \multicolumn{1}{|c|}{$\begin{array}{c}\text { Observed } \\
\text { N }\end{array}$} & $\begin{array}{c}\text { Expected } \\
\text { N }\end{array}$ & Residual \\
\hline $\begin{array}{l}\text { Very low: farmers do not } \\
\text { apply }\end{array}$ & 5 & 9,4 & $-4,4$ \\
\hline Low: farmers will apply & 2 & 9,4 & $-7,4$ \\
\hline $\begin{array}{l}\text { Medium: farmers have } \\
\text { applied but stopped }\end{array}$ & 28 & 9,4 & 18,6 \\
\hline $\begin{array}{l}\text { High: farmers continue to } \\
\text { apply with a fixed planting } \\
\text { area }\end{array}$ & 11 & 9,4 & 1,6 \\
\hline $\begin{array}{l}\text { Very high: farmers continue } \\
\text { to apply with increasing } \\
\text { planting area }\end{array}$ & 1 & 9,4 & $-8,4$ \\
\hline
\end{tabular}

5) Confirmation stage: The confirmation stage is the next stage in the decision making process. In this stage, farmers look for reinforcement in supporting their decision to apply or not to apply organic farming. In this stage the farmer can change his decision. Then, there a question like does it continue to apply or change to reject the application of organic farming? In this research, the confirmation stage is described in the interest of farmers in seeking more information about organic farming. The situation of respondent farmers in Jatianom Village in the confirmation stage is illustrated in Table 9.
TABLE IX. CONFIRMATION StaGE

\begin{tabular}{|l|l|l|l|}
\hline \multicolumn{1}{|c|}{ Variable } & \multicolumn{1}{|c|}{$\begin{array}{c}\text { Observed } \\
\text { N }\end{array}$} & $\begin{array}{c}\text { Expected } \\
\mathbf{N}\end{array}$ & Residual \\
\hline $\begin{array}{l}\text { Low: farmers seek } \\
\text { information from 1 source of } \\
\text { information }\end{array}$ & 46 & 23,5 & 22,5 \\
\hline $\begin{array}{l}\text { Medium: farmers are looking } \\
\text { for information from 2 } \\
\text { sources of information }\end{array}$ & 1 & 23,5 & $-22,5$ \\
\hline
\end{tabular}

Based on table 9, the confirmation stage is significantly related to the decision making of respondent farmers in Jatianom village. This is indicated by the asymp value. sig is 0.004 which means it is below $<0.05$. Almost all respondents of Jatianom Village (except one person) only sought from one source of information. Information obtained from one source has a weakness if the information obtained is incomplete will cause a wrong perception.

\section{CONCLUSION}

The results showed most farmers age are 45-54 years (41\%), most farmers formal education was elementary school $(51,1 \%)$, lowland farmers in general are narrow, ie $0,51-1$ ha $(38,3 \%)$. Farmer's income in general less than 20 million/growth session (42,6\%). Based on the results of chi square goodnes of fit analysis was found that stage of decision making has relationship with decision making farmer to application LEISA are recognition, persuasive, application and confirmation stage.

\section{ACKNOWLEDGMENT}

Authors would like to UGJ research institutions that have funded this research. Thanks also to Sultan Firmansyah, Eva Rosdiana, Rahudi, Ratna, Diana and Dillah for your help in observation.

\section{REFERENCES}

[1] Suliyanto, Statistika non Parametrik dalam Aplikasi Penelitian, Yogyakarta: ANDI, 2014.

[2] S. Aprilyanti, "Pengaruh usia dan masa kerja dalam produktivitas kerja," Jurnal Sistem dan Manajemen Industri, vol. 1, no. 2, pp. 68-72, 2018.

[3] E. Hasudungan Huaturuk, Pengaruh tingkat Pendidikan dan Pengalaman Petani Terhadap Tingkat Produktifitas Tanaman Kopi dan Kontribusinya Terhadap Pengembangan Wilayah Di Kabupaten Tapanuli Utara, 2018. [Online] Retriefed from: www.researchgate.net.

[4] S. Atiqoh, I. Wahyuni, and D. Lestantyo. "Faktor-faktor yang berhubungan dengan kelelahan kerja pada pekerja konveksi bagian penjahitan CV. Aneka Garment Gunungpati Semarang," Jurnal Kesehatan Masyarakat, vol. 2, no. 2 pp. 119-126, February 2014.

[5] BPS, "Rata-Rata Luas Lahan yang Dikuasai Per Rumah Tangga Usaha Pertanian Menurut Wilayah dan Jenis Lahan Tahun 2003 dan 2013 (m2)," 2013. 